\title{
Tolerance and viral resistance after single-dose nevirapine (NVP) and short-course of tenofovir disoproxil fumarate (TDF) and emtricitabine (FTC) to prevent mother-to-child transmission (PMTCT) of HIV-I: the TEmAA ANRS I 2 I 09 phase II trial, step I
}

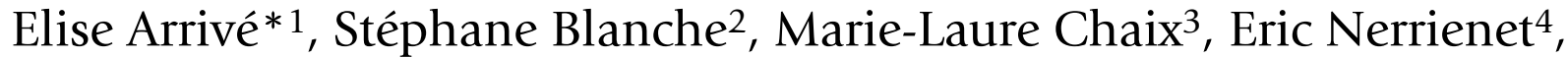
Christine Rouzioux ${ }^{3}$, James McIntyre ${ }^{5}$, Glenda Gray ${ }^{5}$, Patrick Coffie ${ }^{6}$, Kruy Leang Sim7 ${ }^{7}$ Didier Ekouévi ${ }^{6}$ and François Dabis ${ }^{1}$

Address: ${ }^{1}$ Equipe VIH Internationale, INSERM U593, ISPED, Université Victor Segalen, Bordeaux, France, ${ }^{2}$ Service d'Immunologie et Hématologie Pédiatrique, Hôpital Necker Enfants Malades, Paris, France, ${ }^{3}$ Laboratoire de virologie, Hôpital Necker Enfants Malades, Paris, France, ${ }^{4}$ Laboratoire HIV/Hépatites, Institut Pasteur du Cambodge, Phnom Penh, Cambodia, ${ }^{5}$ Perinatal HIV Research Unit (PHRU), University of the Witwatersrand, Soweto, South Africa, ${ }^{6}$ Programme PACCI, ANRS Abidjan, Côte d'Ivoire and ${ }^{7}$ Service Gynécologie-Obstétrique de l'Hôpital Calmette, Phnom Penh, Cambodia

* Corresponding author

from Fourth Dominique Dormont International Conference. Host-Pathogen Interactions in Chronic Infections Paris, France. 13-15 December 2007

Published: 9 April 2008

Retrovirology 2008, 5(Suppl I):O20 doi:I0.I I86/I742-4690-5-SI-O20

This abstract is available from: http://www.retrovirology.com/content/5/SI/O20

(c) 2008 Arrivé et al.; licensee BioMed Central Ltd.

\section{Background}

Viral resistance occurs with high frequency after singledose nevirapine (sdNVP) for PMTCT and alternative regimens are urgently needed [1]. The objective of this study was to evaluate the safety and resistance profile of a combination of TDF (300 mg) and FTC (200 mg) in HIV-1 infected pregnant women and their newborns.

\section{Methods}

The TEmAA ANRS 12109 trial is an open label phase II trial conducted in Ivory Coast, Cambodia and South Africa. SdNVP $(200 \mathrm{mg})$ and 2 tablets of TDF/FTC were given to HIV-1-infected pregnant women at the beginning of labor. One daily tablet of TDF/FTC was given for 7 days postpartum. All women received zidovudine (ZDV, 300 mg BID) from the day of enrollment, between the $28^{\text {th }}$ and $38^{\text {th }}$ week of gestation, until the beginning of labor. All infants received sdNVP syrup on Day $2(2 \mathrm{mg} / \mathrm{kg})$ and ZDV syrup (4mg/kg BID) for 7 days. Mothers and infants were followed for two months. Serious adverse events (SAEs) and HIV-1 infection status of the infants at 3 days and 4 weeks of life were assessed using plasma RNA PCR.
Maternal HIV-1 RNA plasma viral load (VL) was performed at enrolment, day 2 postpartum (PP) and at week 4 PP. Genotypic resistance tests were performed at week 4 PP.

\section{Results}

Thirty-eight HIV-1 infected pregnant women were enrolled (19 in Abidjan, 12 in Phnom Penh and 7 in Soweto): median age 27 years (interquartile range [IQR]: 23-30), median CD4 count 450 cells/mm3 (IQR: 314596) and median HIV-1 RNA VL 4.08 log copies/mL (IQR: 3.60-5.03). All women received TDF/FTC at a median of 4.9 hours before delivery (IQR: $3.0-8.2$ ). Nine (24\%) transient grade $3 / 4$ biological events occurred in mothers during postpartum follow-up ( 3 anaemia, 5 neutropenia and 1 elevation of liver enzymes). Among 39 livebirths (one pair of twins), 9 infants had clinical SAEs (23\%) and 2, transient grade 3 anaemia (5\%). Four children died (1 meningitis, 1 gastroenteritis with malnutrition, 1 intestinal occlusion and 1 unexplained neurological disease) while the other SAEs, with infectious origin (gastroenteritis, bronchopneumonia, meningitis, conjunctivitis and 
neonatal sepsis), resolved. SAEs and deaths were unlikely to be related to TDF/FTC. Two infants out of 38 tested at 4 weeks of life had detectable RNA plasma viral load, also detectable at D3, suggesting in utero HIV infection $(5.3 \%$, 95\% Confidence Interval [CI]: 0.6-17.8). Median maternal HIV VL was $3.3 \log _{10}$ copies/ml at day 2 PP and 4.2 $\log _{10}$ copies/ml at week $4 \mathrm{PP}$. No viral resistance mutations to ZDV, NVP, FTC, and TDF were found in 19 mothers tested at week 4 PP. Remaining tests are ongoing.

\section{Conclusion}

A TDF/FTC combination for PMTCT was well tolerated in women and exposed newborns with no intrapartum HIV transmission reported. Providing 7 days of additional PP antiretroviral exposure with TDF/FTC immediately after sdNVP+TDF/FTC extended the suppression of viral replication avoiding a PP exposure to sdNVP. The second step of the trial will now look for the optimal neonatal dose of TDF and FTC to introduce in this PMTCT regimen.

\section{Acknowledgments}

We acknowledge the sponsors, ANRS and EDCTP, for their support. We would like to thanks the study teams and the mothers and their children who participated in the trial.

\section{References}

I. Arrivé E, Newell ML, Ekouevi DK, Chaix C, Thiébaut R, Masquelier B, leroy V, Van De Perre P, Rouzioux C, Dabis F, Ghent Group on HIV in Women and Children: Prevalence of resistance to nevirapine in mothers and children after single-dose exposure to prevent vertical transmission of HIV-I: a meta-analysis. Int $J$ Epidemiol 2007, 36(4): 1009-102I. doi:I0.1093/ije/dym 104
Publish with Bio Med Central and every scientist can read your work free of charge

"BioMed Central will be the most significant development for disseminating the results of biomedical research in our lifetime. " Sir Paul Nurse, Cancer Research UK

Your research papers will be:

- available free of charge to the entire biomedical community

- peer reviewed and published immediately upon acceptance

- cited in PubMed and archived on PubMed Central

- yours - you keep the copyright

Submit your manuscript here:

http://www.biomedcentral.com/info/publishing_adv.asp 